\title{
Pelatihan Metode Penelitian Tindakan Kelas untuk Meningkatkan Kualitas Pembelajaran di SMPK Santa Clara Surabaya
}

\author{
N. Tri Suswanto Saptadi \\ Jurusan Teknik Informatika, Universitas Atma Jaya Makassar \\ Author E-mail: tri_saptadi@lecturer.uajm.ac.id
}

\begin{abstract}
A B S T R A K
Tugas guru adalah meningkatkan kualitas pembelajaran secara sistematis dan terkendali melalui pemanfaatan penelitian pendidikan. Hasil wawancara dengan Kepala Sekolah di SMPK Santa Clara Surabaya, telah diperoleh informasi bahwa sebagian besar guru belum mampu meningkatkan kualitas pembelajaran. Pelatihan Penelitian Tindakan Kelas (PTK) diharapkan menjadikan partisipan mampu memahami dan menerapkan metode penelitian pendidikan untuk membantu memecahkan permasalahan pembelajaran. Metode pelatihan meliputi penjelasan mengenai materi, pemberian tugas, pembuatan proposal, presentasi individu, pembahasan tugas, penilaian presentasi dan evaluasi pelatihan. Hasil evaluasi pelatihan yang dilakukan melalui aplikasi Google Form menunjukkan bahwa 7 peserta $(58,3 \%)$ menyatakan cukup, 3 peserta (25\%) menyatakan baik, dan 2 peserta (16,7\%) menyatakan sangat baik dalam memahami dan menerapkan pembuatan proposal PTK berdasarkan metode pelatihan yang digunakan. Hasil penilaian presentasi proposal PTK menunjukkan nilai kriteria sangat baik dengan rincian yang memilih kriteria penampilan sebanyak 5 orang $(41,6 \%)$, yang memilih penguasaan materi, 3 peserta (25\%), yang memilih kualitas materi 4 peserta (33,3\%), yang memilih kriteria penggunaan waktu 5 peserta $(41,6 \%)$ dan yang memilih kriteria kemampuan menjawab adalah 4 peserta $(33,3 \%)$.
\end{abstract}

Kata Kunci: Pelatihan, Penelitian Tindakan Kelas, Peningkatan Kualitas.

\section{A B S T R A C T}

The task of the teacher is to improve the quality of learning in a systematic and controlled manner through the use of educational research. The results of interviews with the principal at SMPK Santa Clara Surabaya is showing that most teachers have not been able to improve the quality of learning. Classroom Action Research (CAR) training is expected to be able to give understanding and apply educational research methods to help solve learning problems. The training methods include how to do material explanation, assignment, proposal making, individual presentation, task discussion, presentation assessment and training evaluation. The results of the training evaluation conducted through the Google Form application showed that 7 participants (58.3\%) stated it was sufficient, 3 participants (25\%) said it was good, and 2 participants (16.7\%) stated that it was very good. The training method 
that was used was easy to understand and implement in the form of classroom action research proposals. The results of the assessment of the PTK (CAR) proposal presentation showed a very good criterion with the detail as follows: 5 people (41.6\%) chose based on the performance criteria, 3 participants $(25 \%)$ chose based on the mastery of the content, 4 participants (33.3\%) chose based on the quality of material, 5 participants ( $41.6 \%$ ) chose based on the usage of time and 4 participants (33.3\%) chose based on the ability to answer questions during the training.

Keywords: Training, Classroom Action Research, Quality Improvement.

Copyright (c) 2021 Authors. This is an open access article distributed under the Creative Commons Attribution License, which permits unrestricted use, distribution, and reproduction in any medium, provided the original work is properly cited.

\section{PENDAHULUAN}

Pimpinan SMPK Santa Clara Surabaya senantiasa berupaya meningkatkan kualitas pembelajaran dengan mengadakan pelatihan dan peningkatan kapasitas bagi guru dan tenaga kependidikan setiap tahun. Kendala yang dihadapi sekolah adalah sebagian besar guru belum mampu meningkatkan kualitas pembelajaran. UndangUndang Nomor 14 Tahun 2005 tentang Guru dan Dosen mengamanatkan bahwa tenaga pendidik harus mempunyai kualifikasi akademik, kompetensi, sertifikat pendidik, dan kemampuan yang dipersyaratkan untuk mewujudkan tujuan pendidikan nasional. Guru profesional dibuktikan dengan dokumen sertifikat pendidik. Menurut Suwarno (2014), pendidikan adalah upaya pembinaan kepribadian yang relevan melalui nilai yang dianut oleh masyarakat yang berbudaya. Pendidikan berhubungan dengan pendidik dan peserta didik yang memiliki kedudukan dan perasaan yang berbeda namun memerlukan daya yang relatif sesuai dengan upaya mempengaruhi pelaksanaan proses pendidikan sehingga terjadi transformasi pengetahuan dan keterampilan untuk mencapai tujuan yang diharapkan. Pendidikan mensyaratkan proses untuk mencapai sasaran pembelajaran (Suprijono, 2012) sehingga membentuk suatu pola kebiasaan, tindakan, nilai, pengertian, sikap, apresiasi dan ketrampilan. Sementara Dimyati dan Mudjiono (2009) menyampaikan bahwa hasil belajar bergantung pada interaksi tindakan belajar dan mengajar di mana guru menjalankan tugas yang diakhiri dengan proses evaluasi hasil belajar.
Standar Nasional Pendidikan (PP. No. 19 Tahun 2005) menginstruksikan kepada guru untuk meningkatkan kualitas pembelajaran dan kompetensi melalui berbagai kemampuan secara: Pedagogik: Manajemen pembelajaran peserta didik, desain dan penerapan, evaluasi hasil belajar, serta peningkatan kemampuan peserta didik untuk mengembangkan beragam potensi; Kepribadian: relevan, stabil, dewasa, berwibawa, keteladanan, beriman, dan berperilaku baik; Profesional: penguasaan materi pembelajaran secara umum dan mendetail dalam mendampingi peserta didik; dan Sosial: menjadi bagian masyarakat yang mampu berkolaborasi dan bersinergi secara efektif bersama seluruh stakeholders.

Untuk meningkatkan pemahaman dan kemampuan dalam kompetensi pedagogik diperlukan pelatihan Classroom Action Research, Penelitian Tindakan di Kelas (PTK). Menurut Kemmis, Stephen dan Robin Mc Taggart (1988), PTK merupakan penelitian dari aksi pembelajaran yang dilakukan di dalam kelas dengan tahapan penyelidikan terkontrol yang berulang dan bersifat reflektif dan individual. Tujuannya adalah untuk melakukan perbaikan terhadap sistem, cara kerja, proses, konten, kompetensi, atau ruang lingkup dari pembelajaran. Menurut Salim, Manalu dan Zairin (2015), penelitian tindakan adalah suatu bentuk penelitian reflektif secara bersama yang dilakukan oleh peserta untuk menambah penalaran dan menunjang praktik pendidikan yang adil, serta pemahaman terhadap praktik 
dan kondisi dari lokasi tempat pembelajaran. Menurut Elliot (1982), penelitian tindakan adalah ulasan tentang keadaan sosial pembelajaran dengan tujuan meningkatkan kualitas tindakan dan proses yang diperlukan untuk mengkaji, menganalisis, merencanakan, melaksanakan, memonitor, dan saling mempengaruhi dalam upaya membangun hubungan yang dibutuhkan untuk mengevaluasi diri dan mengembangkan diri secara profesional.

PTK menurut Kemendikbud (2017) bertujuan untuk menyempurnakan praktik; menambah profesionalitas dalam hal memperkaya pengetahuan para praktisi terhadap praktik pembelajaran yang dilakukan; dan membenarkan suatu keadaan atau situasi di mana praktik pembelajaran dilaksanakan. PTK memiliki manfaat untuk memperoleh laporan sebagai rujukan para pendidik untuk meningkatkan kualitas; menciptakan habitus, budaya, dan tradisi riset dengan menulis artikel ilmiah; menghasilkan kerja sama, kolaborasi, dan bersinergi antara pendidik sebagai upaya untuk memecahkan masalah dalam pembelajaran dan meningkatkan mutu; menambah kapasitas pendidik dalam menjabarkan kurikulum sesuai perkembangan; membina keterlibatan, kegairahan, keinginan, kedamaian, dan kegembiraan siswa dalam mengikuti proses pembelajaran di kelas; mendorong terciptanya pembelajaran yang menarik, menantang, nyaman, membahagiakan, serta memotivasi siswa melalui strategi, metode, teknik, dan sarana media dalam pembelajaran yang bervariasi dan dirancang secara tepat. PTK memberikan manfaat dan merupakan bentuk upaya guru dalam melakukan riset individu melalui praktik pembelajaran yang dilaksanakan di kelas. Guru dapat mengkombinasikan dan berinovasi dalam melaksanakan tugas keseharian sehingga tidak harus mengorbankan target kurikulum yang akan dicapai dengan menjembatani kesenjangan antara teori pembelajaran dan praktik di kelas. Pelaksanaan belajar-mengajar guru dapat dilihat, dirasakan dan dihayati secara konsisten melalui praktik pembelajaran yang telah dilaksanakan secara efektif, efisien dan relevan.
PTK memiliki karakter seperti on the job problem oriented, problem solving oriented, improvement oriented, cyclic, action oriented, penelaahan pada suatu tindakan, specifics contextual, participatory, menerapkan refleksi, dan menggunakan metode berdasarkan langkah perencanaan, tindakan, pengamatan, refleksi, yang diulang terus menerus dalam beberapa siklus.

\section{METODE PELAKSANAAN}

\section{Khalayak Sasaran}

Pelatihan metode Penelitian Tindakan Kelas (PTK) dilaksanakan di Sekolah Menengah Pertama Katolik (SMPK) Santa Clara Surabaya pada tanggal 31 Juli dan 7 Agustus 2021 (selama 2 hari). Pelatihan menggunakan aplikasi MSTeams dengan jumlah peserta yang mengikuti sebanyak 12 orang. Metode pelatihan meliputi penjelasan materi, pemberian tugas, pembuatan proposal, presentasi individu, pembahasan tugas, penilaian presentasi dan evaluasi pelatihan.

\section{Metode Pelatihan}

1. Penjelasan Materi, yaitu pelatihan diawali dengan pemaparan materi mengenai definisi penelitian tindakan kelas yang merupakan metode dalam memecahkan permasalahan pembelajaran yang berbasis pada evaluasi. Penjelasan materi terdiri dari sejarah, peraturan menteri negara pendayagunaan aparatur negara (Permen PAN dan RB, 2009), tujuan dan hasil, karakteristik, prinsip umum, pendekatan SMART (penetapan tujuan specific, measurable, achievable, relevant, dan time-based), konsep dasar, manfaat, dan langkah pokok dalam PTK.

2. Pemberian Tugas, yaitu setiap peserta diberikan tugas membuat proposal PTK dengan tema tertentu dalam jangka waktu selama 1 (satu) minggu dengan mengikuti kaidah dan aturan penulisan yang didasarkan pada penjelasan dalam pembuatan proposal.

3. Pembuatan Proposal, konten proposal PTK berisi judul, daftar isi, pendahuluan, permasalahan, tujuan, manfaat, tinjauan dan landasan teori, metode penelitian, dan daftar pustaka. 
4. Presentasi Individu, setiap peserta melakukan presentasi secara mandiri berdasarkan tema yang telah diusulkan. Waktu yang diberian dalam presentasi selama 15 (lima belas) menit dengan pembagian waktu 7 (tujuh) menit pemaparan dan 8 (delapan) menit tanya jawab. Setiap peserta yang presentasi akan mendapatkan tanggapan, masukan, dan evaluasi dari narasumber.

5. Pembahasan Tugas, setiap proposal yang dipaparkan kemudian dibahas berdasarkan konten yang berisi pendahuluan, tinjauan pustaka dan landasan teori, metode penelitian serta daftar pustaka yang menjadi rujukan.

6. Penilaian Presentasi, setelah presentasi peserta dilaksanakan kemudian diberikan nilai berdasarkan kriteria penampilan, penguasaan materi, kualitas materi, penggunaan waktu, dan kemampuan menjawab.

7. Evaluasi Pelatihan, setelah seluruh kegiatan dilaksanakan kemudian peserta dan pihak sekolah (kepala sekolah) diberikan kesempatan untuk memberi pesan dan kesan selama pelaksanaan pelatihan sebagai upaya peningkatan kualitas pelatihan.

\section{Langkah Pelatihan}

Keberhasilan pelatihan ditentukan dengan keikutsertaan peserta yang telah direkomendasikan oleh pihak sekolah sebagai upaya peningkatan kualitas pembelajaran di kelas. Beberapa langkah kegiatan yang telah dilakukan untuk mendukung kesuksesan pelaksanaan program pengabdian kepada masyarakat, yaitu:

1. Mengajukan izin kepada Kepala Sekolah SMP Katolik Santa Clara Surabaya.

2. Melakukan koordinasi dengan peserta pelatihan yaitu guru dan tendik (tenaga pendidik) yang baru.

3. Memberi undangan kepada peserta pelatihan.

4. Melaksanakan pelatihan selama 2 hari dari jam 09.00-13.00 WIB.

5. Membuat evaluasi dan laporan hasil pelatihan.

\section{HASIL DAN PEMBAHASAN}

\section{Hasil}

Sebelum pelatihan, dilakukan wawancara kepada kepala sekolah dan beberapa guru muda mengenai kendala yang dihadapi dalam upaya meningkatkan kualitas pembelajaran. Sebagian besar guru muda (90\%) belum mengetahui dan memahami bahwa metode PTK dapat meningkatkan kualitas pembelajaran di sekolah. Parameter yang dijadikan standar penilaian kualitas pembelajaran selama ini berupa pengamatan dan wawancara yang dilakukan kepala sekolah terhadap guru setelah proses belajar-mengajar. Sementara penelitian tindakan sebagai sebuah proses penyelidikan terkontrol yang berulang dan bersifat reflektif individu dengan tujuan melakukan perbaikan terhadap sistem, cara kerja, proses, konten, kompetensi, atau ruang lingkup.

1. Demografi Responden

Status demografi responden ditentukan berdasarkan jenis kelamin, umur, status pegawai, serta tahun mulai mengajar atau bekerja di sekolah. Dari 12 peserta, hanya 10 peserta yang mengisi kuesioner evaluasi pelatihan.

a. Jenis Kelamin

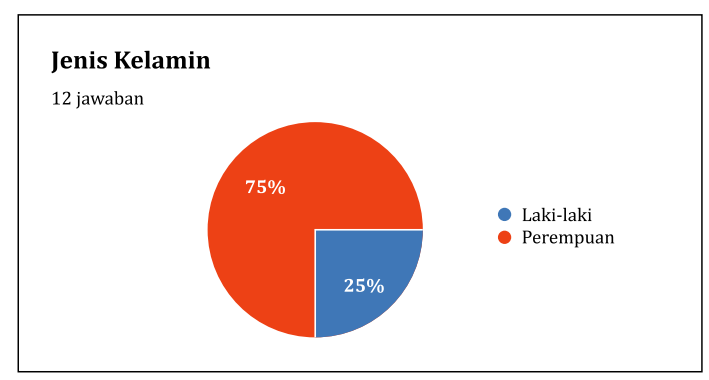

b. Umur

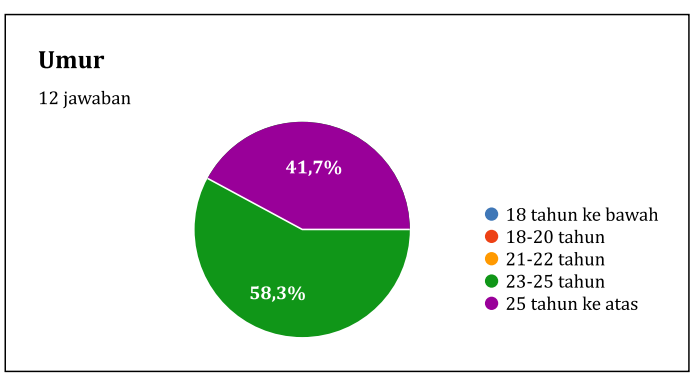




\section{c. Status Pegawai}

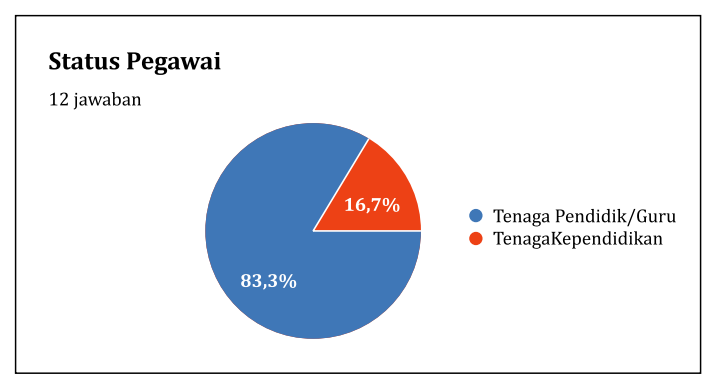

d. Tahun mulai mengajar atau bekerja di sekolah

Tahun mulai mengajar atau bekerja di sekolah 12 jawaban

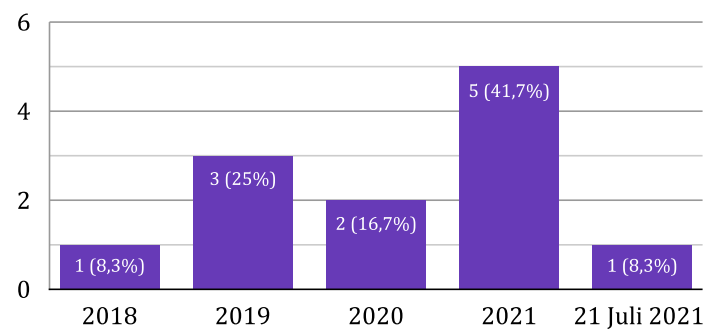

2. Kuesioner

Kuesioner yang berjumlah 11 pertanyaan diberikan kepada peserta sebagai responden untuk mendapatkan tanggapan terhadap pelaksanaan pelatihan metode Penelitian Tindakan Kelas (PTK).

a. Apakah pelatihan bermanfaat untuk meningkatkan kualitas diri

Apakah pelatihan bermanfaat untuk meningkatkan kualitas diri 12 jawaban

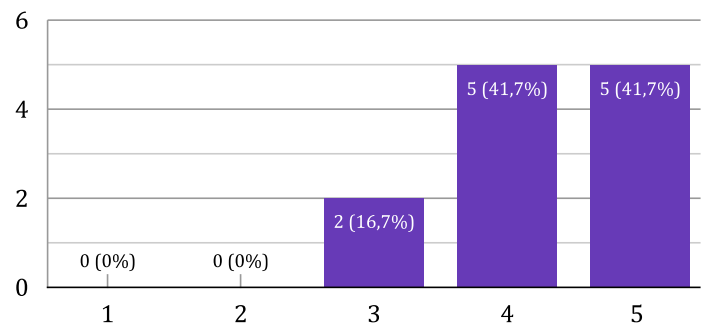

b. Apakah materi pelatihan dapat dipahami dengan baik

Apakah materi pelatihan dapat dipahami dengan baik

12 jawaban

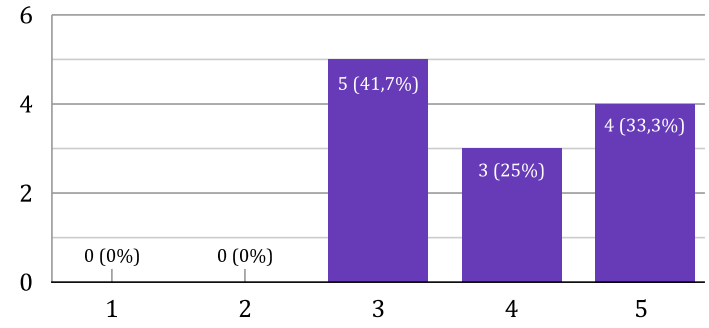

c. Apakah metode PTK yang diberikan saat pelatihan sesuai dengan kebutuhan

Apakah metode PTK yang diberikan saat pelatihan sesuai dengan kebutuhan

12 jawaban

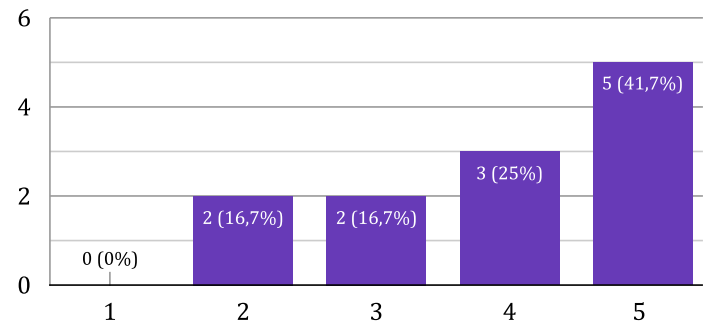

d. Apakah tugas membuat proposal saat pelatihan dapat dikerjakan dengan baik

Apakah tugas membuat proposal saat pelatihan dapat dikerjakan dengan baik

12 jawaban

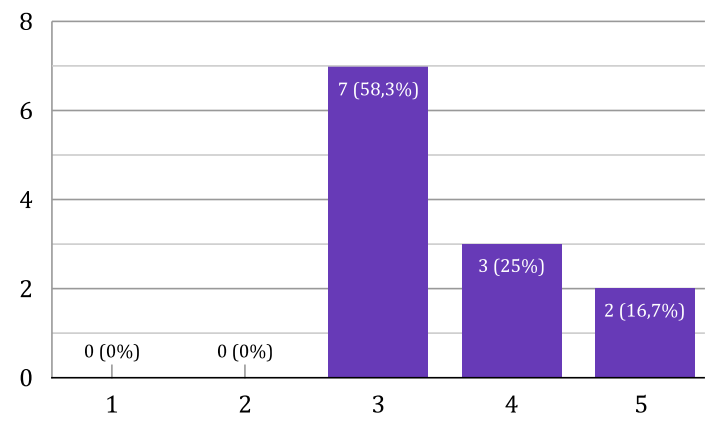


e. Apakah waktu pelatihan dapat diikuti secara efektif

Apakah waktu pelatihan dapat diikuti secara efektif

12 jawaban

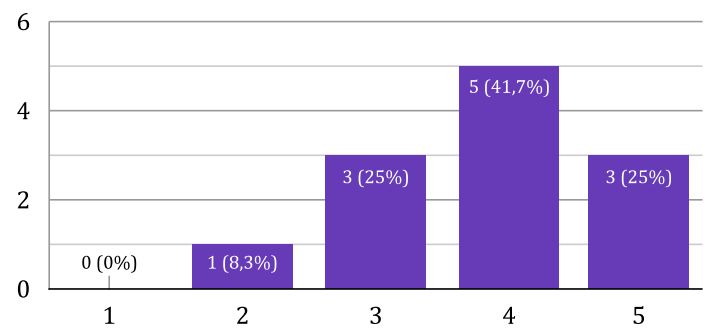

f. Apakah narasumber menguasai materi dengan baik

Apakah narasumber menguasai materi dengan baik 12 jawaban

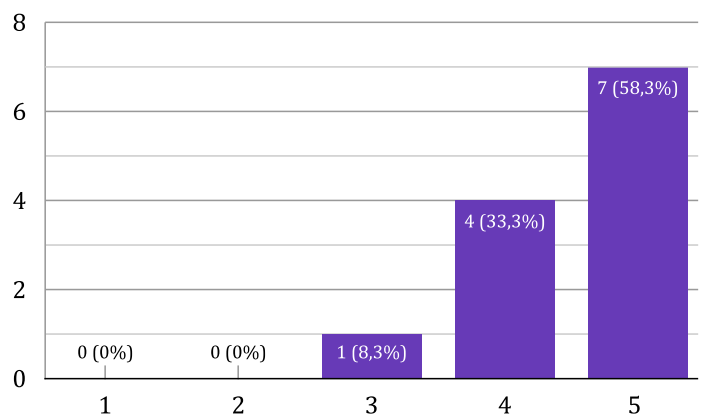

g. Apakah bahan presentasi (slide) menarik dan lengkap

Apakah bahan presentasi (slide) menarik dan lengkap 12 jawaban

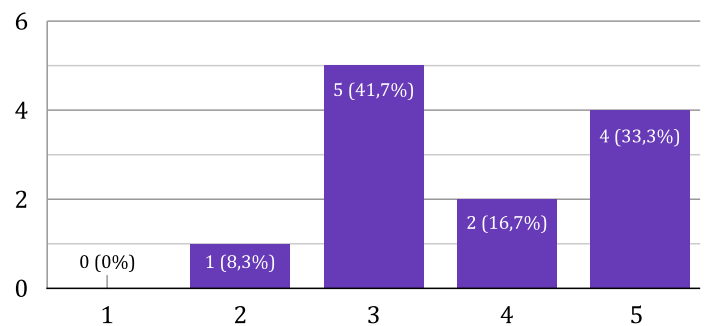

h. Apakah narasumber memberikan waktu untuk diskusi dan tanya-jawab dengan baik

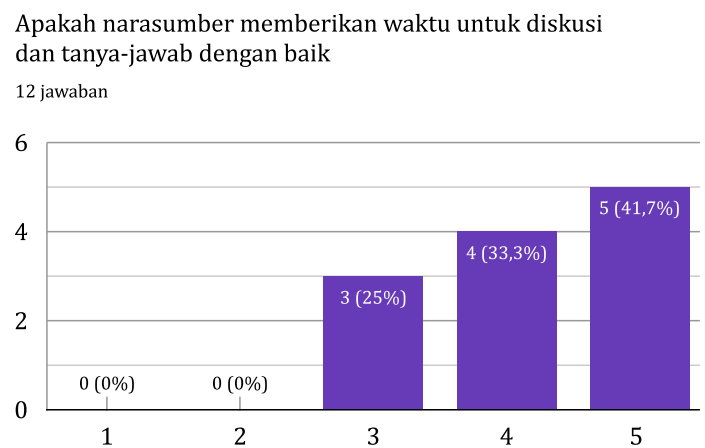

i. Apakah narasumber memberikan latihan /tugas/studi kasus yang relevan dengan materi

Apakah narasumber memberikan latihan/tugas/studi kasus yang relevan dengan materi

12 jawaban

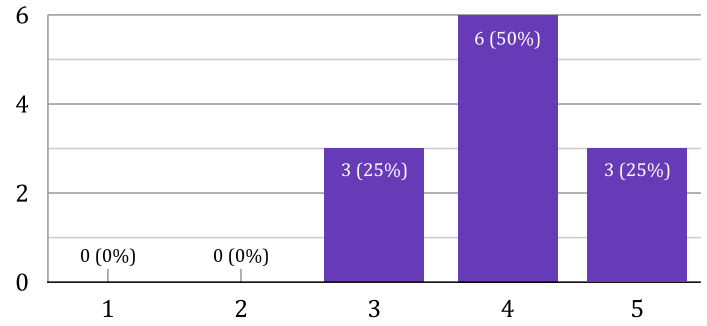

j. Apakah sekolah telah menyediakan dukungan sarana dan prasarana untuk pelatihan PTK dengan baik

Apakah sekolah telah menyediakan dukungan sarana dan prasarana untuk pelatihan PTK dengan baik

12 jawaban

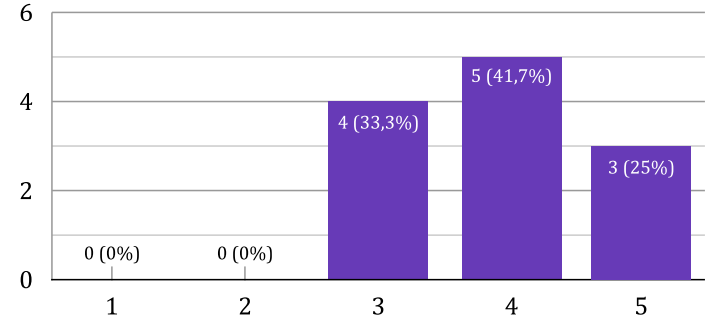


k. Apakah usulan materi selanjutnya

Apakah usulan materi selanjutnya

12 jawaban

Mengurangi tingkat plagiarisme dalam penelitian
Pelatihan praktik model mengajar yang baik
Lebih menari lagi materinya supaya tidak membosankan. lalu untuk
waktu, mohon sedikit dikurangi karena kami juga punya kegiatan
atau tugas tang lain. terimakasih
Melanjutkan materi minggu lalu
Kembali memahami materi yang lalu di ajarkan. Saya belum
sepenuhnya memahami cara menjelaskan hasil VOS
Cara memilah siswa yang perlu pendampingan kusus dengan sistem
yang baik
Tentang revolusi industri 4.0
terimakasih dan blm punya ide/usulan, krn masih dalam tahap
penyesuaian
-
Materi yg berkaitan dgn teknologi aplikasi yang kreatif untuk
mengajar
Jika ada pelatihan, materinya berkaitandengan proses pembelajaran
yang relevan
Tidak Ada

\section{Pembahasan}

\section{Pelaksanaan Pelatihan}

Pelatihan diikuti oleh 12 orang guru dan tendik dengan menggunakan metode berupa penjelasan materi, pemberian tugas, pembuatan proposal, presentasi individu, pembahasan tugas, penilaian presentasi dan evaluasi pelatihan. Pelatihan diawali dengan doa pembukaan yang dilanjutkan dengan sambutan dari kepala sekolah Sr. Elisabeth Hardiantinawati, MC., S.Pd., M.Pd. yang mengajak kepada peserta untuk bersungguhsungguh dalam mengikuti pelatihan serta mampu menerapkan pengetahuan dan keterampilan yang telah diperoleh dalam upaya mendukung peningkatan kualitas belajar-mengajar. Materi pelatihan meliputi berbagai metode PTK yang mungkin dapat diterapkan di sekolah. Tahapan PTK meliputi mendefinisikan permasalahan, perencanaan tindakan kelas, pelaksanaan tindakan, pengamatan atau pengumpulan data dan refleksi. Setelah semua materi diberikan, kemudian pelatihan diakhiri dengan doa penutup oleh salah seorang peserta yang mengikuti pelatihan.
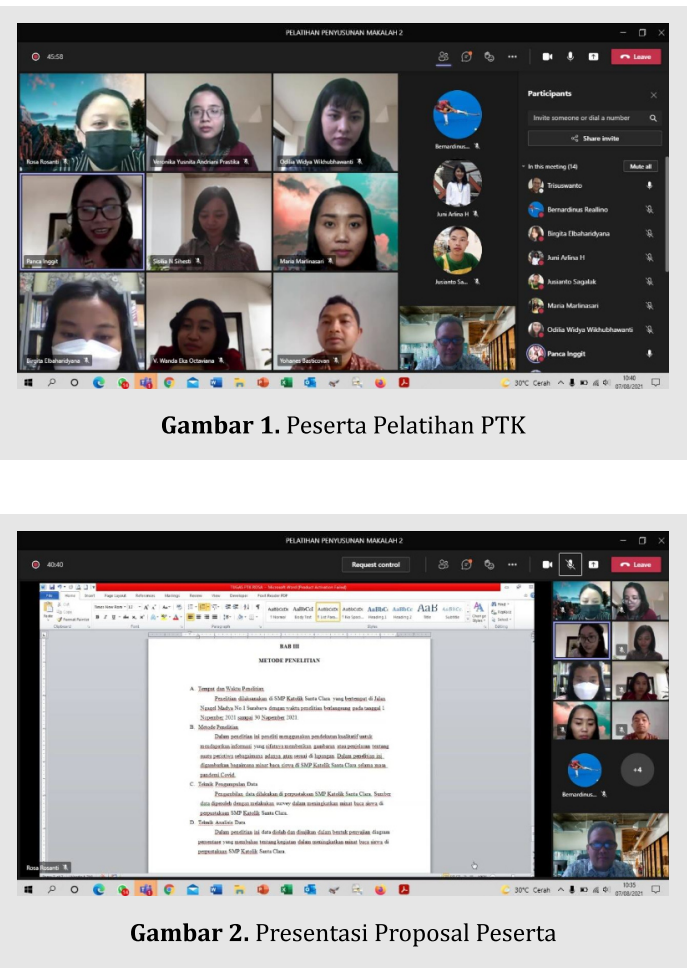

2. Hasil Pelaksanaan Metode Pelatihan

a. Penjelasan materi

Peserta mengikuti pelatihan dengan sungguh-sungguh yang dibuktikan melalui kehadiran dari awal hingga akhir. Selama pelatihan PTK peserta memperhatikan materi yang diberikan meliputi sejarah, peraturan menteri negara pendayagunaan aparatur negara, tujuan dan hasil, karakteristik, prinsip umum, pendekatan SMART, konsep dasar, manfaat, dan langkah pokok PTK. Beberapa peserta memanfaatkan waktu dengan bertanya dan menyampaikan kasus yang tengah dihadapi di kelas untuk memperoleh jawaban dan alternatif solusi dalam memecahkan permasalahan pembelajaran.

b. Pemberian tugas

Setiap peserta diberikan tugas membuat proposal PTK dengan tema tertentu dengan jangka waktu pengerjaan selama 1 (satu) minggu dengan mengikuti kaidah dan aturan penulisan berdasarkan penjelasan dalam pembuatan proposal. Selama mengerjakan tugas, peserta mengalami kendala seperti harus dapat 
membagi waktu untuk melaksanakan tugas pokok sebagai pengajar dan mengerjakan pekerjaan rutin administratif.

c. Pembuatan proposal

Proposal PTK berisi judul, pendahuluan, permasalahan, tujuan, manfaat, tinjauan dan landasan teori, metode penelitian, serta daftar pustaka. Hasil pekerjaan tugas yang diberikan, beberapa peserta mampu menyusun proposal dengan baik meskipun terdapat pula peserta yang belum dapat menyelesaikan dengan baik. Kendala yang dihadapi adalah belum menemukan ide mengenai topik atau masalah yang akan ditulis, terbatasnya referensi yang relevan dan up to date. Selain itu peserta terkendala dalam merumuskan masalah dan menentukan metode penelitian.

d. Presentasi individu

Setiap peserta melakukan presentasi berdasarkan tema yang diusulkan. Waktu yang diberikan dalam presentasi selama 15 (lima belas) menit dengan pembagian 7 (tujuh) menit pemaparan dan 8 (delapan) menit tanya jawab dari peserta yang hadir dan tanggapan narasumber. Dalam pelaksanaan presentasi, beberapa peserta terkendala dalam menyajikan tayangan proposal dengan aplikasi MSTeams yang digunakan. Terdapat peserta yang belum mampu menyampaikan secara lengkap karena terkendala waktu dan referensi yang memadai.

e. Pembahasan tugas

Setiap proposal yang dipaparkan oleh peserta kemudian dibahas berdasarkan pola penulisan yang berisi pendahuluan, landasan teori, metode penelitian dan daftar pustaka yang digunakan. Peserta telah mampu mengerjakan tugas secara sistematis dengan mengikuti pola yang diberikan. Namun demikian masih terdapat pula peserta yang belum menyelesaikan tugas hingga pada bagian daftar pustaka yang dikarenakan kesibukan dalam menjalankan tugas pokok sehari-hari.

f. Penilaian presentasi

Setelah presentasi dilaksanakan kemudian diberikan nilai berdasarkan penampilan, penguasaan materi, kualitas materi, penggunaan waktu, dan kemampuan menjawab. Penilaian terhadap peserta dapat dilihat pada tabel berikut:

g. Evaluasi pelatihan

Setelah seluruh kegiatan dilaksanakan, peserta dan pihak sekolah (kepala sekolah) diberikan kesempatan untuk menyampaikan pesan dan kesan selama pelaksanaan pelatihan. Pesan yang disampaikan kepala sekolah kepada peserta adalah harapan agar pelatihan ini bermanfaat bagi peningkatan kemampuan guru dan tendik dalam melaksanakan tugas belajar-mengajar. Kepala sekolah juga menyampaikan kesan bahwa setiap peserta telah mampu mengikuti pelatihan secara bersungguh-sungguh dan penuh perhatian dengan mengerjakan tugas yang diberikan.

Table 1. Penilaian Presentasi berdasarkan Peserta

\begin{tabular}{|c|c|c|c|c|c|c|c|}
\hline \multirow{2}{*}{ No } & \multirow{2}{*}{ Kriteria } & \multicolumn{5}{|c|}{ Nilai Presentasi } & \multirow{2}{*}{ Jumlah Peserta } \\
\hline & & $<60$ & $61-70$ & 71-80 & $81-90$ & 91-100 & \\
\hline 1 & Penampilan & 0 & $1(8,33 \%)$ & $2(16,6 \%)$ & $4(33,3 \%)$ & $5(41,6 \%)$ & 12 \\
\hline 2 & Penguasaan Materi & 0 & $1(8,33 \%)$ & $3(25 \%)$ & $5(41,6 \%)$ & $3(25 \%)$ & 12 \\
\hline 3 & Kualitas Materi & $1(8,33 \%)$ & $2(16,6 \%)$ & $2(16,6 \%)$ & $3(25 \%)$ & $4(33,3 \%)$ & 12 \\
\hline 4 & Penggunaan Waktu & 0 & 0 & $3(25 \%)$ & $4(33,3 \%)$ & $5(41,6 \%)$ & 12 \\
\hline \multirow[t]{2}{*}{5} & Kemampuan Menjawab & $1(8,33 \%)$ & $2(16,6 \%)$ & $2(16,6 \%)$ & $3(25 \%)$ & $4(33,3 \%)$ & 12 \\
\hline & Jumlah & 2 & 6 & 12 & 19 & 21 & 60 \\
\hline
\end{tabular}




\section{KESIMPULAN DAN SARAN}

Berdasarkan kegiatan pengabdian kepada masyarakat yang telah dilaksanakan, maka pelaksanaan pelatihan PTK dapat disimpulkan sebagai berikut:

1. Hasil evaluasi pelatihan yang dilakukan melalui aplikasi Google Form menunjukkan bahwa terdapat 7 peserta $(58,3 \%)$ menyatakan cukup, 3 peserta (25\%) menyatakan baik, dan 2 peserta $(16,7 \%)$ menyatakan sangat baik sehingga memahami dan mampu menerapkan pembuatan proposal PTK berdasarkan metoda yang diajarkan di dalam pelatihan.

2. Hasil penilaian presentasi proposal PTK menunjukkan nilai sangat baik dengan rincian berdasarkan kriteria penampilan dipilih oleh 5 orang $(41,6 \%)$, berdasarkan penguasaan materi dipilih oleh 3 peserta (25\%), berdasarkan kualitas materi dipilih oleh 4 peserta $(33,3 \%)$, berdasarkan penggunaan waktu dipilih oleh 5 peserta $(41,6 \%)$ dan berdasarkan kemampuan menjawab dipilih oleh 4 peserta $(33,3 \%)$.

\section{Ucapan Terima Kasih}

Terima kasih kepada Sekolah Menengah Pertama Katolik Santa Clara Surabaya yang telah memberikan dukungan dalam melaksanakan pengabdian kepada masyarakat khususnya bagi guru dan tenaga kependidikan. Terima kasih kepada program studi Teknik Informatika yang telah mendukung kegiatan pengabdian kepada masyarakat ini.

\section{R E F E R E N C E}

Undang-Undang Nomor 14 Tahun 2005 tentang Guru dan Dosen.

Suwarno, Wiji. (2014). Dasar-dasar Ilmu Pendidikan. Yogyakarta: Ar-Ruzz Media.

Sudijono, Anas. (2014). Pengantar Evaluasi Pendidikan. PT. Raja Grafindo Persada. Jakarta.

Dimyati dan Mudjiono. (2009). Belajar dan Pembelajaran. Jakarta: Rineka Cipta.

Peraturan Pemerintah Nomor 19 Tahun 2005 tentang Standar Nasional Pendidikan

Kemmis, Stephen dan Robin Mc Taggart. (1988). The Action Research. Panner, 3rd ed Victoria: Deakin University PTK.

Salim, Manalu dan Zairina. (2015). Penelitian Tindakan Kelas. Perdana Mulya Sarana. Medan.

Elliot, John (1982). Developing Hypothesis abot Classroom from Teachers Practical Constructs: an Account of the Work of the Ford Teaching Project - The Action Researsch Reader. Geelong: Deakin University.

Kemendikbud. (2017). Penyusunan Karya Tulis Ilmiah - Penelitian Tindakan Kelas. Modul Diklat Perencanaan Pendidikan. Kementerian Pendidikan dan Kebudayaan.

Kunandar. (2008). Langkah Mudah Penelitian Tindak Kelas sebagai Pengembangan Profesi Guru. Jakarta: PT. Raja Grafindo Persada.

Peraturan Menteri Negara pendayaan Aparatur Negara dan Reformasi Birokrasi (Permen PAN dan RB) Nomor 16 Tahun 2009 tentang Jabatan Fungsional Guru dan Angka Kreditnya. 